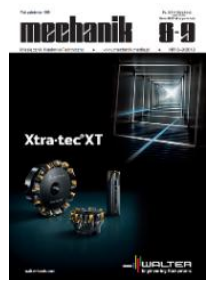

How to cite this article:

Authors: Maciej Majcher, Stanisław Wrzesień, Michał Frant

Title of article: „Numerical and experimental verification of analytical project of the axial fan”

Mechanik, No. 8-9 (2019)

DOI: https://doi.org/10.17814/mechanik.2019.8-9.75

\title{
Numerical and experimental verification of analytical project of the axial fan
}

\author{
MACIEJ MAJCHER \\ STANISŁAW WRZESIEŃ \\ MICHAŁ FRANT *
}

\author{
Mgr inż. Maciej Majcher, maciej.majcher@wat.edu.pl, https://orcid.org/0000-0002-4094-8766 - Wojskowa Akademia Techniczna, \\ Warszawa, Polska \\ Dr hab. inż. Stanisław Wrzesień, stanislaw.wrzesien@wat.edu.pl, https://orcid.org/0000-0002-4543-1256 - Wojskowa Akademia \\ Techniczna, Warszawa, Polska \\ Dr inż. Michał Frant, michal.frant@wat.edu.pl, https://orcid.org/0000-0002-1372-9242 - Wojskowa Akademia Techniczna, Warszawa, \\ Polska
}

The paper presents a comparison of basic axial fan characteristics obtained by three research methods: analytical, experimental and numerical. Characteristics of the total pressure, efficiency and power were analyzed. The influence of the geometry deviation of the manufactured rotor rim from the assumptions resulting from the analytical design was discussed. The correctness of the axial fan designing scheme based on analytical, numerical and experimental methods was confirmed.

KEYWORDS: CFD, characteristics of axial fans, fluid-flow machines

\section{Introduction}

Starting point in the design of axial fans are analytical algorithms based on the rectilinear palisade model. A palisade is called an infinite series of identical profiles with chords parallel to each other and arranged in such a way that any corresponding profile points lie on a straight line [9].

Like any analytical model, the rectilinear palisade model has advantages and quite significant disadvantages. Its advantages include: simplicity of flow kinematics description, ability to estimate the characteristics of the designed fan and ease of determining the geometry of the fan in relation to the assumed performance. The most important disadvantages of rectilinear palisade model are the inability to accurately estimate flow losses and the inability to take into account the interaction between the rotor and steering rim as well as negative aerodynamic phenomena (e.g. detachment), and above all, reducing the flow to a case of steady flat flow. These simplifications do not allow for full coverage of the phenomena occurring in the actual flow of the working medium through the blade rims of this type of machine. Hence the need to verify analytical designs of axial fans.

The analysis of the state of the issue $[5,8,13]$ shows that numerical tests allow for obtaining the qualitative and quantitative results convergent with results of experimental tests. Therefore, numerical simulations can be successfully used to verify axial fan designs implemented on the basis of an analytical algorithm, which will minimize the number of experimental tests.

\section{Analytical design of the fan}

The analytical design of the rotor rim and steering axial fan was made on the basis of algorithms available in the literature [7, 10,11]. The starting point for the analytical project was the nominal volume flow of $Q=8 \mathrm{~m}^{3} / \mathrm{s}$ and the assumed outer and inner diameter of $700 \mathrm{~mm}$ and $450 \mathrm{~mm}$, respectively. For such defined data, it was determined that the range of total pressure increase (fan compression) should fluctuate within $\Delta p_{\mathrm{c}}=3000 \div 3300 \mathrm{~Pa}$. 
As mentioned, analytical algorithms are based on a straight palisade model, an example of which is shown in fig. 1. In the analytical design of the fan, for seven selected cross-sections of the rotor blade, the chord of the profile $l$, the pitch of the palisade $t$ and the angle of setting the profiles in the palisade were determined based on the calculated blade angles: $\beta_{1}{ }^{*}$ and $\beta_{2}{ }^{*}$ and $\alpha_{2}{ }^{*}$ and $\alpha_{3}{ }^{*}$, respectively for the rotor and steering rim (fig. 1).

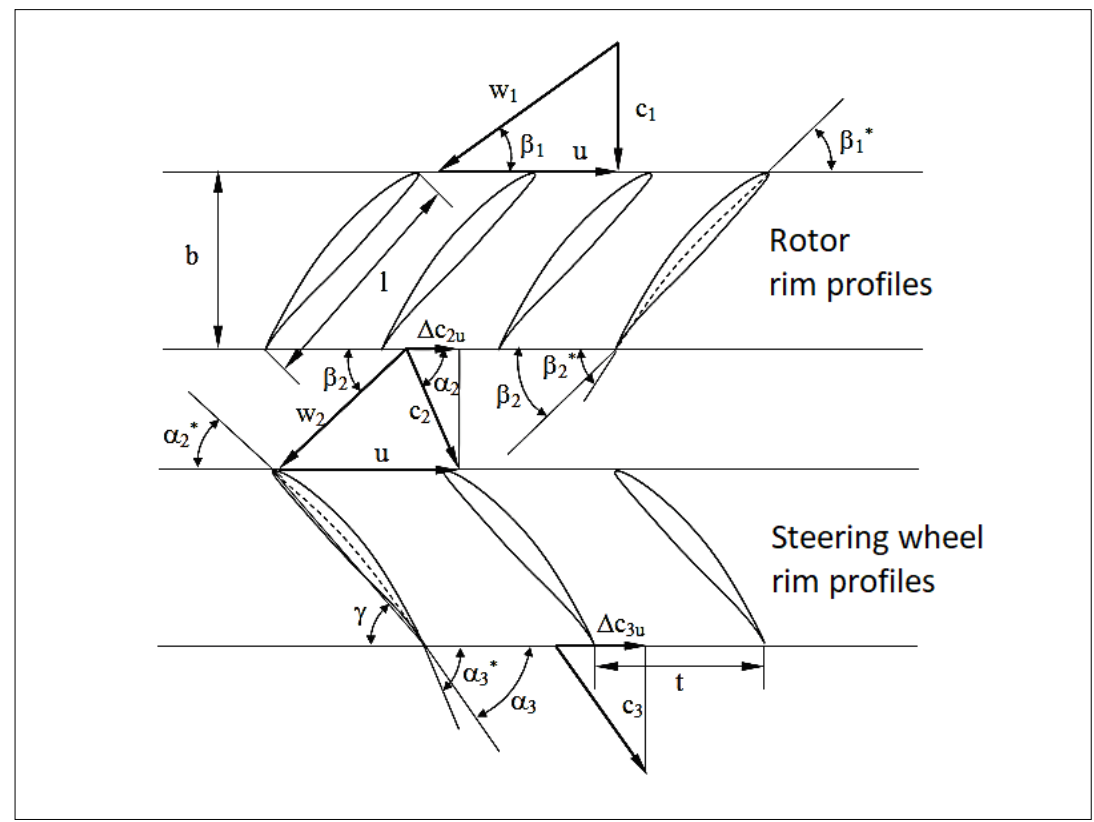

Fig. 1. Straight profile palisade [12]

It was assumed that the profile of 14 rotor blades is NACA 65-810, the characteristics of which in the palisade system are generally available [4]. It was proposed that seven steering blades be made of $3 \mathrm{~mm}$ thick bent sheet metal. Theoretical characteristics of the designed fan were also determined.

To verify the analytical calculations, numerical simulations of flow through the designed fan were carried out. Satisfactory compliance of analytical and numerical results was obtained, thus the fan design was approved and submitted for production.

\section{Methodology of numerical analyses}

Numerical analysis of flow through fan blade rims was carried out in Ansys Fluent software with implemented computer fluid mechanics methods. Numerical simulations were carried out using the average Navier-Stokes equations, referred to as Reynolds Averaged Navier-Stokes (RANS) [6].

The RANS system of equations is not closed and a complete set of equations defining the components of the turbulent stress tensor should be added to its closure [6]. In the case of computer fluid mechanics, these equations result from the turbulence model used. The present model uses the realizable $k-\varepsilon$ type.

The following characteristics of the axial fan were the result of a series of numerical analyses:

- course of total pressure as a function of volumetric flow rate: $\Delta p_{\mathrm{c}}=f(Q)$,

- total efficiency as a function of volumetric flow rate: $\eta=f(Q)$,

- power course as a function of volumetric flow rate: $P=f(Q)$.

\section{Restoration of rotor rim geometry}

The actual axial fan was produced based on data from the analytical design. In order to verify the correctness of performance, geometry of the final rotor was reproduced using reverse engineering optical scanning. The actual rotor rim was scanned with the GOM ATOS 2 optical scanner. It works by analyzing lines in a series of images of bands projected onto the surface of the scanned object. The bands are recorded by the device's camera and processed using algorithms adapted to the parameters of the optical system [3]. The result is a cloud of points with the $x, y, z$ coordinates. 
Based on the obtained point cloud, the scanned geometry was exported in the form of an .stl file with the help of specialized software attached to the scanner for further process of geometry restoration. The final geometry of the rotor rim was obtained using Siemens NX 8.5 software. Result of these operations was virtual solid of the rotor rim, which was compared with the geometry of the rotor rim resulting from the analytical design.

Fig. 2 compares the geometry of manufactured rotor rim (red) with geometry resulting from the analytical design (green). As it can be seen, geometry of the actual rim deviates from the geometry determined in the analytical design, and the deviation of the trailing edge from the design assumptions was about $4 \mathrm{~mm}$ at the tip of the blade. The difference is due to the fan technology. Therefore, numerical simulations of flow through the blade rims of the manufactured fan were carried out to determine the impact of the difference in geometry on its performance.

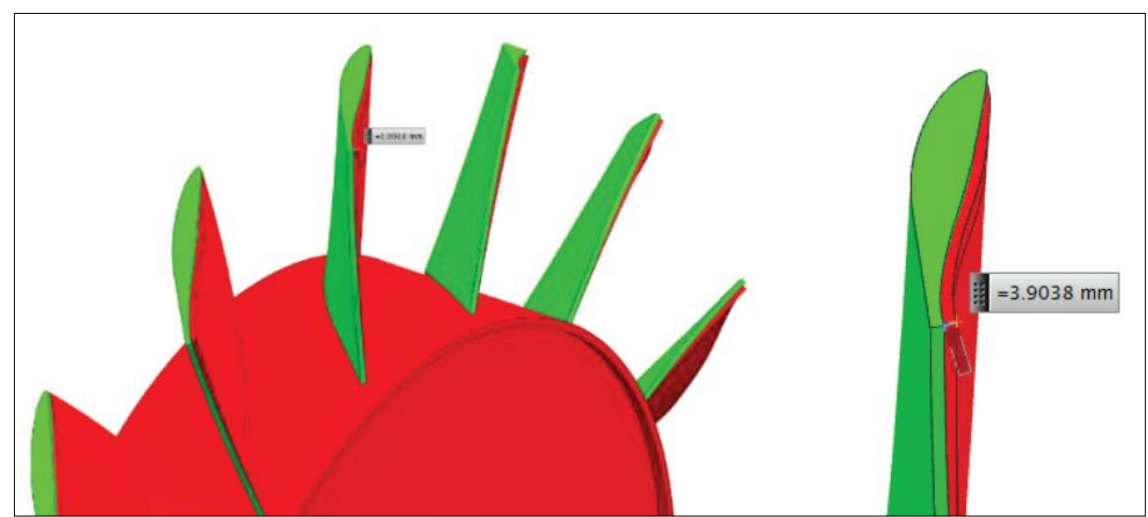

Fig. 2. Comparison of geometry of the manufactured rotor rim (red) and geometry resulting from its analytical design (green)

\section{Comparison of numerical simulation results with experimental and analytical results}

Basic fan operation characteristics were analyzed as a function of volumetric flow rate obtained experimentally and numerically. Simulations of flow through the designed fan were made for the rotor rim steering rim system. The MRF (Multiple Reference Frame) model was applied allowing the use of periodic boundary conditions, and the Mixing Plane model [1]. The Mixing Plane model enables numerical analyses for a steady-state flow case in rotor machines, in which the number of rotor blades is not an integral multiple of the number of guide blades and vice versa.

In fig. $3 a-c$, the characteristics obtained from experimental tests are marked in black, and characteristics obtained numerically for fan geometry resulting from the analytical design are marked in green. The red color marks the characteristics obtained on the basis of numerical calculations of the scanned rotor rim with attached steering rim, the geometry of which was determined in the analytical design. Fig. $3 a$ shows characteristics of the total pressure increase of the axial fan determined by two methods. Based on the characteristics, it is possible to obtain satisfactory compliance of the experimental and numerical results.

The largest differences in the achieved fan compression are observed for high flow expenditure. For volumetric flow rates $\sim 10.5 \div \sim 12.75 \mathrm{~m}^{3} / \mathrm{s}$, the average relative difference between the experimental and numerical results of the designed geometry was about $20 \%$. As the expenditure decreases, the differences between the characteristics decrease. In the entire range of volumetric flow rates obtained on the test bench, the relative, mean difference between the experimental results and the numerical simulation of the flow through the blade rims determined in the analytical design was about $12 \%$.

Differences in total pressure increases may result from the simulation method. Simulations were carried out for one rotor and steering blade with periodic boundary conditions - the correctness of the blade positioning was not analyzed in the entire rim. In addition, the roughness of blades, the flow channel and the presence of welds were not taken into account during the numerical simulations.

The difference in the design of the rotor rim (see fig. 2) slightly affected the achieved total pressure increase (increased its value). The average relative difference, in the entire expenditure range, in the results obtained by the numerical method for scanned fan geometry and geometry resulting from the analytical design was $3 \%$. 
Fig. $3 b$ shows the performance characteristics of the axial fan obtained experimentally and numerically. There is a clear difference between them. The average relative difference in efficiency determined experimentally and numerically was about $24 \%$. This is mainly due to the method of determining the efficiency by these two methods. The fan efficiency, determined experimentally, is the ratio of stream power to the power of the electric motor driving the rotor rim. In the numerical tests, in determining the efficiency, the engine power is not taken into account, and the flux power refers to the power calculated on the basis of the determined torque and the set speed. In addition, as mentioned, the numerical method did not take into account the roughness of blades, the flow channel and any leaks of the test stand.

a)

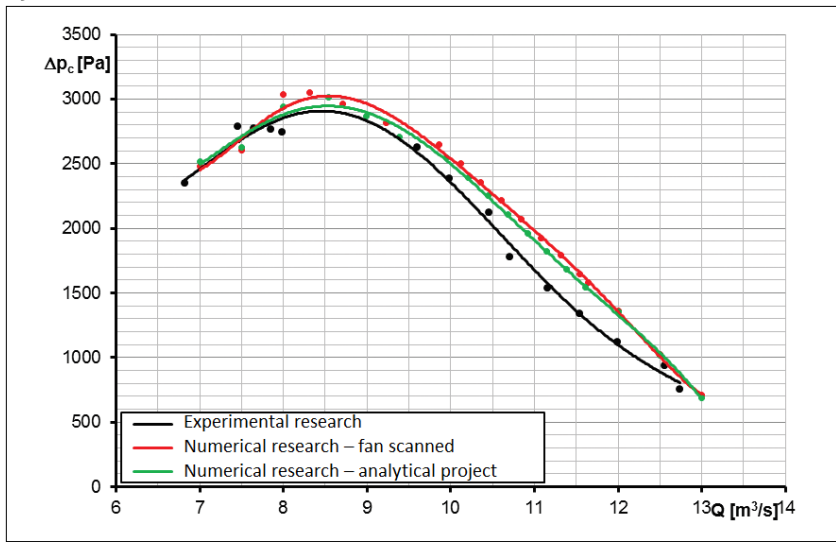

b)

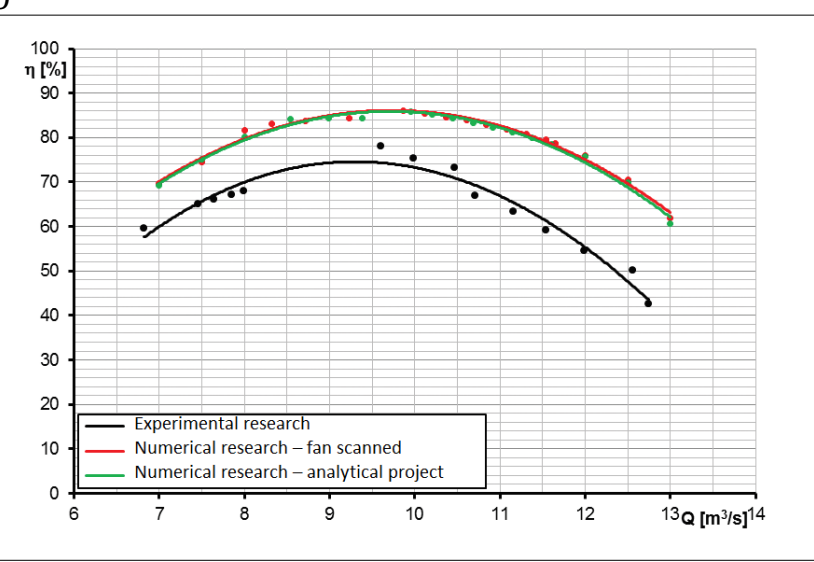

c)

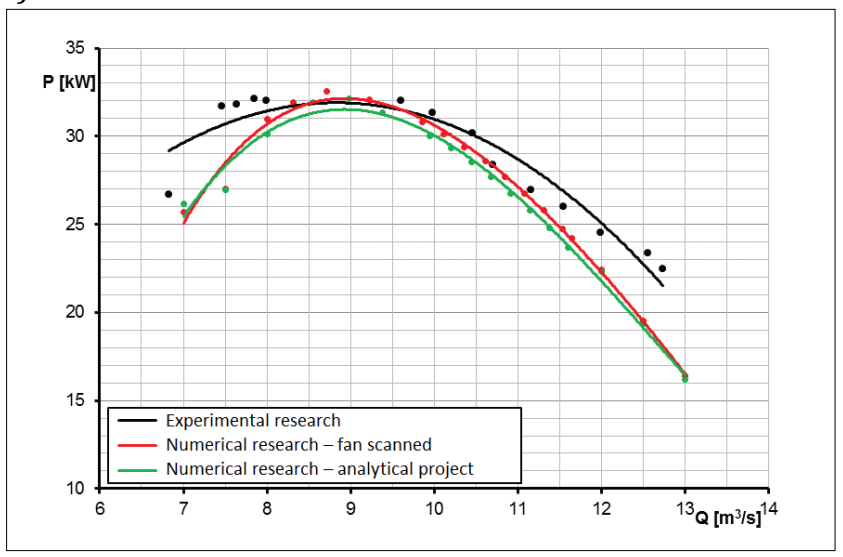

Fig. 3. Characteristics obtained experimentally and numerically: a) of pressure increase as a function of volumetric intensity; b) of efficiency as a function of volumetric intensity; c) of power as a function of volumetric intensity

Analyzing the characteristics obtained on the basis of numerical simulation for scanned geometry and geometry resulting from the analytical design, no significant impact of the discrepancy in the mapping of the rotor blade on its efficiency was found. The average relative difference in achieved efficiency was $\sim 1 \%$ in the entire range of volumetric flow rates obtained in numerical simulations.

Fig. $3 c$ shows the axial fan power characteristics determined by two methods. In the area of average flow expenditure, i.e. $\sim 8 \div \sim 11 \mathrm{~m}^{3} / \mathrm{s}$, satisfactory agreement between experimental and numerical results was obtained. The average, relative difference in power, determined experimentally and numerically, was about $4 \%$.

In terms of high and low flow expenditure, differences in the characteristics are clear. In the range of volumetric flow rates $\sim 11.5 \div \sim 12.75 \mathrm{~m}^{3} / \mathrm{s}$, the average, relative power difference is about $14 \%$, while in the range of $\sim 7 \div \sim 8 \mathrm{~m}^{3} / \mathrm{s}$ this difference is about $8 \%$. The differences mainly result from the previously mentioned ways of determining power by two methods.

It should be noted that deviation in the geometry of the actual rotor rim from the geometry resulting from the analytical design did not have much effect on the power characteristics. The average, relative difference in the numerical characteristics obtained for the scanned fan and geometry determined analytically over the entire range of considered flow expenses is about $2 \%$. 


\section{Summary}

Basic characteristics of the designed axial fan were compared experimentally and numerically. Geometry of the manufactured rotor rim was reproduced by one of the reverse engineering methods and compared with geometry resulting from the completed analytical design. Deviation in the geometry of the actual rim from geometry resulting from analytical calculations was found. Numerical simulations of flow through the fan blade rims and their results were compared with experimental data.

Satisfactory compliance of results of the total pressure increase characteristic was obtained. Performance characteristics obtained with two test methods differ significantly, which results from differences in determining the efficiency based on the results of numerical simulation and from the fact that the numerical method does not include the roughness of blades and the flow channel. For power characteristics, satisfactory results were obtained in terms of average flow expenditure. There was no significant impact of the deviation of actual rotor geometry from geometry determined in the analytical design on the fan performance.

It can be concluded that properly applied axial fan design scheme, based on analytical, numerical and experimental methods, allows for achieving the assumed performance of this type of machine.

\section{REFERENCES}

[1] ANSYS Fluent. 2013. "Theory Guide. Release 15.0".

[2] ANSYS. Release 15. "Meshing User's Guide".

[3] Dziubek T., Oleksy M. „Zastosowanie systemu optycznego ATOS II w technikach szybkiego prototypowania modeli kół zębatych otrzymywanych na bazie żywicy epoksydowej”. Polimery. 62, 1 (2017): 44-51, dx.doi.org/10.14314/polimery.2017.044.

[4] Emery J., Herrig J., Erwin J., Felix R. "Systematic two-dimensional cascade tests of NACA 65-series compressor blades at low speed". NACA Technical Report. 1368. USA: National Advisory Committee for Aeronautics. Langley Aeronautical Lab, 1958, http://hdl.handle.net/2060/19930093730.

[5] Junger C., Zenger F., Reppenhagen A., Kaltenbacher M., Becker S. "Numerical Simulation of a Benchmark Case for Aerodynamics and Aeroacoustics of a Low Pressure Axial Fan". 45th International Congress and Exposition on Noise Control Engineering Inter Noise. Hamburg, 2016.

[6] Kazimierski Z. „Podstawy mechaniki płynów i metod komputerowej symulacji przepływu”. Łódź: Wydawnictwo Politechniki Łódzkiej, 2004.

[7] Kuczewski S. „Wentylatory”. Warszawa: Wydawnictwa Naukowo-Techniczne, 1978.

[8] O'Halloran S., Hannukainen P., Makkonen P., Meyer L., Kumar V., Krosser M. “Fan Modeling Validation Using CFD". Summary of Proceedings. NAFEMS World Congress. USA, 2015.

[9] Rościszewski J. „Aerodynamika stosowana”. Warszawa: Wydawnictwo MON, 1957.

[10] Tuliszka E. „Sprężarki, dmuchawy i wentylatory”. Warszawa: Wydawnictwa Naukowo-Techniczne, 1976.

[11] Witkowski A. „Sprężarki wirnikowe. Teoria, konstrukcja, eksploatacja”. Gliwice: Wydawnictwo Politechniki Śląskiej, 2013.

[12] Wrzesień S., Frant M., Majcher M. „Numeryczna analiza charakterystyk wentylatora osiowego”. Mechanik. 7 (2018): 606-608, https://doi.org/10.17814/mechanik.2018.7.98.

[13] Younsi M., Lavedrine J. "Unsteady Flow and Acoustic Behaviour of an Axial Fan: Numerical and Experimental Investigations". Proceedings of $11^{\text {th }}$ European Conference on Turbomachinery Fluid dynamics \& Thermodynamics ETC11. Spain, 2015. 